\title{
Metazoan Parasite Faunas of Three Gobiid Species (Actinopterygii: Gobiidae) Inhabiting the Lower Kızılırmak Delta in Samsun: A Comparative Study
}

\author{
Samsun’ da Aşağı Kızılırmak Deltasında Yaşayan Üç Kaya Balığının (Actinopterygii: Gobiidae) \\ Karşılaştırmalı Metazoan Parazit Faunası
}

\author{
Arzu Güven 미, Türkay Öztürk \\ Department of Fish Diseases, Sinop University Faculty of Fisheries and Aquatic Sciences, Sinop, Türkiye
}

Cite this article as: Güven A, Öztürk T. Metazoan Parasite Faunas of Three Gobiid Species (Actinopterygii: Gobiidae) Inhabiting the Lower Kızlırmak Delta in Samsun: A Comparative Study. Turkiye Parazitol Derg 2018; 42:33-8.

\section{ABSTRACT}

Objective: The aim of the present study was to investigate and compare metazoan parasite faunas of three gobiid fishes, Neogobius fluviatilis, Proterorhinus marmoratus, and Pomatoschistus marmoratus, inhabiting the Lower Kızılırmak Delta.

Methods: Fish specimens were caught using fishing nets and electroshock device. The fishes were transferred to the laboratory and examined under a dissecting microscope for metazoan parasites using conventional methods. The isolated parasites were fixed with $70 \%$ ethyl alcohol. The Czekanowski-Sørensen Index (ICS) was used for comparing the metazoan faunas of the three gobiid fishes.

Results: Overall, 13 metazoan parasite species comprising 2 monogeneans (Gyrodactylus proterorhini and Gyrodactylus sp.), 6 digenean metacercariae (Tylodelphys clavata, Diplostomum spathaceum, Apatemon gracilis, Posthodiplostomum sp., Ascocotyle sp., and Echinostoma sp.), 1 cestoda (Bothriocephalus acheilognathi), 3 nematodes (Spiroxys contortus, Eustrongylides excisus, and Contraceacum rudolphii), and 1 arthropoda Ergasilus (sieboldin) were observed. The maximum parasite diversity was found in N. fluviatilis; Po. marmoratus had significantly fewer parasitic species (4). Total parasite abundance was significantly high in Pr. marmoratus, which was infected with 9 parasite species. A closer resemblance was observed in the parasite faunas of $\mathrm{N}$. fluviatilis and Pr. marmoratus (ICS=80.0\%).

Conclusions: To the best of our knowledge, this is the first study on metazoan parasite faunas of N. fluviatilis, Pr. marmoratus, and Po. marmoratus in Turkey.

Keywords: Black Sea, gobiid fishes, Lower Kızılırmak Delta, metazoan parasites, Turkey

Received: 30.10 .2017

Accepted: 11.12 .2017

\section{ÖZ}

Amaç: Bu çalışmanın amacı, Aşağı Kızılırmak Deltasında yaşayan 3 kaya balığının, Neogobius fluviatilis, Proterorhinus marmoratus ve Pomatoschistus marmoratus metazoan parazit faunalarını araştırmak ve karşılaştırmaktır.

Yöntemler: Kaya balıkları, balık ağları ve elektroşok cihazıyla yakalandı. Balıklar laboratuvara nakledildi ve metazoan parazitleri için klasik yöntemlerle disseke mikroskop altında incelendi. İzole edilen parazitler \%70 etil alkol ile tespit edildi. Üç kaya balığının metazoan faunalarını karşılaştırmak için Czekanowski-Sorensen indeksi (Ics) kullanıldı.

Bulgular: 2 monogenea Gyrodactylus proterorhini ve Gyrodactylus sp., 6 digenea (metaserker) Tylodelphys clavata, Diplostomum spathaceum, Apatemon gracilis, Posthodiplostomum sp., Ascocotyle sp., ve Echinostoma sp., bir sestod, Bothriocephalus acheilognathi, üç nematod Spiroxys contortus, Eustrongylides excisus, Contraceacum rudolphii ve bir arthropod Ergasilus sieboldii olmak üzere toplamda 13 metazoan parazit türü belirlendi. Maksimum parazit tür çeşitliliği N. fluviatilis'de bulundu. Pomatoschistus marmoratus'un tür sayısı (4) daha azdı. Toplam parazit bolluğu 9 parazit türü ile infekte Proterorhinus marmoratus'da belirgin olarak daha yüksekti. N. fluviatilis ve Pr. marmoratus'un parazit faunalarında benzerlik gözlemlendi (lcs: \%80,0).

Sonuç: Bu çalışma, N. fluviatilis, Pr. marmoratus ve Po. marmoratus'un metazoan parazit faunaları üzerine Türkiye'de ilk rapordur.

Anahtar sözcükler: Karadeniz, kaya balıkları, Aşağı Kızılırmak Deltası, metazoan parazit, Türkiye

Geliş Tarihi: 30.10.2017

Kabul Tarihi: 11.12.2017

Address for Correspondence / Yazışma Adresi: Türkay Öztürk E.mail: turkay.ozturk@gmail.com DOI: 10.5152/tpd.2018.5635

CCopyright 2018 Turkish Society for Parasitology - Available online at www.turkiyeparazitolderg.org

(CTelif hakkı 2018 Türkiye Parazitoloji Derneği - Makale metnine www.turkiyeparazitolderg.org web sayfasından ulaşılabilir. 


\section{INTRODUCTION}

The family Gobiidae is one of the largest taxons of fish and vertebrate animals. It comprises $>2000$ species with $>200$ genera. They are abundant worldwide in every kind of environment, including tropical to temperate marine, estuarine, and freshwater (1). A total of 5 out of 27 species of this family, which inhabited the Black Sea (2), Neogobius, Proterorhinus, and Pomatoschistus are the most common genera of the family. Neogobius fluviatilis and Proterorhinus marmoratus are native species in the PontoCaspian basin. Their native habitats include the coastal zones of the Black Sea, Caspian Sea, Azov Sea, and Marmara Sea (3-5). Pomatoschistus marmoratus is a species of the Mediterranean Basin and is widespread in the Eastern Atlantic, Mediterranean, Black Sea, Azov Sea, and Suez Canal $(3,6)$. The gobiid fishes play important roles in the ecosystem. Regarding food chains, the gobies are secondary consumers and are themselves prey for larger fish, sea birds, and seals. Their availability for predators implies that they are important transmitters of parasites, which complete their life cycle in several hosts (7). Gobiids may be definitive, intermediate, or paratenic hosts of parasites such as digeneans, cestodes, and nematodes. Owing to their ecological tolerance, small sizes, habitation, and diversity, gobiids are appropriate fishes to study the course of colonization by parasites (8).

Several studies are available about the helminths of lagoons and estuaries in the northwestern Black Sea (9-21). Although there is considerable information available on the parasite fauna of gobiids mainly from the northern coasts of the Black Sea, only few studies have reported on those of the gobiids that reside close to Turkish coasts (22-24). In Turkey, there is so far only one published study on the metazoan parasite fauna of Neogobius melanostomus, which is not a gobiid species investigated in the present study (23). Moreover, no published study has reported on the metazoan parasites of $N$. fluviatilis, Pr. marmoratus, and Po. marmoratus from the southern coast of the Black Sea so far. Thus, more studies are required to determine the metazoan parasite fauna of various gobiid species.

The aim of the present study was to investigate and compare the metazoan parasite faunas that occur on N. fluviatilis, Pr. marmoratus, and Po. marmoratus from the Lower Kızılırmak Delta located on the southern coastal zones of the Black Sea. The results are comparable with those of a few previous studies, which investigated in different coastal zones from the Black Sea. The results of the present study present new data about parasitehost relationship.

\section{METHODS}

The three gobiid species were fished from the Lower Kızılırmak Delta, which is located on the border of Samsun city (41 $38^{\prime} 38.84^{\prime \prime}$ $\mathrm{N}$ and $36^{\circ} 04^{\prime} 09.89^{\prime \prime} \mathrm{E}$ ) and lies at the sea level. The specimens of these fishes were caught using fishing nets and electroshock device. Sampling was conducted over a 1-year period. A total of 221 specimens of the three gobiid species, N. fluviatilis (160), Pr. marmoratus (45), and Po. marmoratus (16), were investigated for the presence of helminths. The fishes were measured and weighed, and their external and internal organs were carefully examined.

\section{Parasitological Indices and Statistical Analysis}

The prevalence, mean intensity, and abundance for metazoan parasites from monkey goby N. fluviatilis, tubenose goby Pr. mar-

Table 1. Component community of parasites of three gobiid fishes from the Lower Kızılırmak Delta (bold data for homogeneity)

\begin{tabular}{|c|c|c|c|c|c|c|c|c|c|}
\hline \multirow[b]{2}{*}{ Host species } & \multicolumn{3}{|c|}{$\begin{array}{l}\text { Neogobius fluviatilis } \\
(n=160)\end{array}$} & \multicolumn{3}{|c|}{$\begin{array}{l}\text { Proterorhinus marmoratus } \\
\qquad(n=45)\end{array}$} & \multicolumn{3}{|c|}{$\begin{array}{l}\text { Pomatoschistus marmoratus } \\
\qquad(n=16)\end{array}$} \\
\hline & $\mathbf{P}$ & $\mathrm{Ml} \pm \mathrm{SE}$ & A & $\mathbf{P}$ & $\mathrm{Ml} \pm \mathrm{SE}$ & A & $\mathbf{P}$ & $\mathrm{Ml} \pm \mathrm{SE}$ & A \\
\hline Gyrodactylus proterorhini & 9.4 & $2.7 \pm 0.6$ & 0.25 & 28.9 & $15.2 \pm 3.9$ & 4.40 & 12.5 & $2.5 \pm 05$ & 0.31 \\
\hline Gyrodactylus sp. & - & - & - & - & - & - & 6.25 & $26.0 \pm 0.0$ & 1.63 \\
\hline Ascocotyle sp. met. & 4.4 & $1.3 \pm 0.2$ & 0.06 & - & - & - & - & - & - \\
\hline Echinostoma sp. met. & 60.0 & $16.7 \pm 2.1$ & 10.03 & 37.8 & $15.4 \pm 5.3$ & 5.82 & 25 & $1.3 \pm 0.3$ & 0.31 \\
\hline Tylodelphys clavata met. & 15.0 & $3.5 \pm 1.8$ & 1.19 & 28.9 & $4.8 \pm 1.4$ & 1.38 & 18.8 & $1.0 \pm 0.0$ & 0.19 \\
\hline $\begin{array}{l}\text { Diplostomum } \\
\text { spathaceum met. }\end{array}$ & 18.8 & $6.6 \pm 1.4$ & 1.24 & 13.3 & $2.0 \pm 0.6$ & 0.27 & - & - & - \\
\hline Apatemon gracilis met. & 3.8 & $5.0 \pm 2.1$ & 0.19 & 46.7 & $63.9 \pm 16.2$ & 29.84 & - & - & - \\
\hline $\begin{array}{l}\text { Posthodiplostomum sp. } \\
\text { met. }\end{array}$ & 6.3 & $5.7 \pm 2.3$ & 0.36 & 17.8 & $38.9 \pm 12.6$ & 6.91 & - & - & - \\
\hline $\begin{array}{l}\text { Bothriocephalus } \\
\text { acheilognathi pl. }\end{array}$ & 5.0 & $1.4 \pm 0.3$ & 0.07 & 17.8 & $1.3 \pm 0.2$ & 0.22 & - & - & - \\
\hline Spiroxys contortus $L 3$ & 2.5 & $1.4 \pm 0.4$ & 0.04 & - & - & - & - & - & - \\
\hline Eustrongylides excisus L3 & 2.5 & $1.6 \pm 0.6$ & 0.05 & - & - & - & - & - & - \\
\hline Contraceacum rudolphii L3 & - & - & - & 8.9 & $1.8 \pm 0.5$ & 0.16 & - & - & - \\
\hline Ergasilus sieboldi & 8.8 & $1.3 \pm 1.2$ & 0.31 & 2.2 & $1.0 \pm 0.00$ & 0.02 & - & - & - \\
\hline Total & 75 & $18.4 \pm 2.1^{\mathrm{ab}}$ & 13.78 & 77.8 & $63.0 \pm 15.4^{b}$ & 49.02 & 43.8 & $6.0 \pm 4.0^{a}$ & 2.63 \\
\hline
\end{tabular}


Table 2. Infracommunity index

\begin{tabular}{|c|c|c|c|}
\hline & $\begin{array}{l}\text { Neogobius } \\
\text { fluviatilis }\end{array}$ & $\begin{array}{c}\text { Proterorhinus } \\
\text { marmoratus }\end{array}$ & $\begin{array}{c}\text { Pomatoschistus } \\
\text { marmoratus }\end{array}$ \\
\hline $\begin{array}{l}\text { Gyrodactylus } \\
\text { proterorhini }\end{array}$ & 0.07 & 0.14 & 0.30 \\
\hline Gyrodactylus sp. & & & 0.09 \\
\hline Ascocotyle sp. met. & 0.03 & & \\
\hline $\begin{array}{l}\text { Echinostoma sp. } \\
\text { met. }\end{array}$ & 0.44 & 0.24 & 0.40 \\
\hline $\begin{array}{l}\text { Tylodelphys clavata } \\
\text { met. }\end{array}$ & 0.11 & 0.14 & 0.30 \\
\hline $\begin{array}{l}\text { Diplostomum } \\
\text { spathaceum met. }\end{array}$ & 0.14 & 0.07 & \\
\hline $\begin{array}{l}\text { Apatemon gracilis } \\
\text { met. }\end{array}$ & 0.03 & 0.23 & \\
\hline $\begin{array}{l}\text { Posthodiplosto- } \\
\text { mum sp. met. }\end{array}$ & 0.05 & 0.09 & \\
\hline $\begin{array}{l}\text { Bothriocephalus } \\
\text { acheilognathi pl. }\end{array}$ & 0.04 & 0.09 & \\
\hline $\begin{array}{l}\text { Spiroxys contortus } \\
\text { L3 }\end{array}$ & 0.02 & & \\
\hline $\begin{array}{l}\text { Eustrongylides } \\
\text { excisus L3 }\end{array}$ & 0.02 & & \\
\hline $\begin{array}{l}\text { Contraceacum } \\
\text { rudolphii L3 }\end{array}$ & & 0.04 & \\
\hline Ergasilus sieboldi & 0.06 & 0.01 & \\
\hline Mean infracommunity & 1.82 & 2.02 & 1.43 \\
\hline Species richness & 11 & 9 & 4 \\
\hline Shannon Index & 1.06 & 1.30 & 0.99 \\
\hline Species evenness & 0.44 & 0.56 & 0.72 \\
\hline \multicolumn{4}{|c|}{$\begin{array}{l}(\mathrm{ICl}>0.30) \text {. met.: metacercaria; pl.: plerocercoid, L3: L3 stage; ICl: } \\
\text { infracommunity index }\end{array}$} \\
\hline
\end{tabular}

moratus, and marbled goby Po. Marmoratus were determined according to Bush et al. (25). The standard error for mean intensity is provided. The Czekanowski-Sørensen Index (ICS, \%) was used to compare the helminth faunas (26). The significance of the host-parasite relationship was determined according to the abundance values. The scales used for species were $>2$ for core species, 0.6-2 for secondary species, 0.2-0.6 for satellite species, and 0.2 for rare species (27). The tendency to participate in the infracommunity was evaluated in terms of the infracommunity index with $>0.30$ as the highest value. The mean infracommunity was characterized as the mean number of parasite species per host individual (28). The species evenness was calculated according to the formula provided by Zander et al. (7). The evenness values $>$ 0.6 represented a greater part of the homogeneity with $>0.7$ being a high homogeneity. All statistical tests were carried out using GraphPad Instat 3.0 for Windows 2000 (Software, San Diego, CA, USA) software ( $p<0.05$ : statistically significant).

\section{RESULTS}

In total, the following 13 metazoan parasite species were found: 2 monogenea (Gyrodactylus proterorhini and Gyrodactylus sp.) 6
Table 3. Czekanowski-Sørensen Index (\%) in helminth fauna of various gobiid species in the study area

\begin{tabular}{|l|c|c|c|}
\hline & Nf & Pr & Po \\
\hline Neogobius fluviatilis (Nf) & 100.0 & - & - \\
\hline Proterorhinus marmoratus (Pr) & 80.0 & 100 & - \\
\hline Pomatoschistus marmoratus (Po) & 40.0 & 46.0 & 100 \\
\hline
\end{tabular}

digenean metacercariae (Tylodelphys clavata, Diplostomum spathaceum, Apatemon gracilis, Posthodiplostomum sp., Ascocotyle sp., and Echinostoma sp.), 1 cestoda (Bothriocephalus acheilognathi), 3 nematodes (Spiroxys contortus, Eustrongylides excisus, and Contraceacum rudolphii), and 1 arthropoda Ergasilus (sieboldi). The monkey goby has the richest parasite fauna with 11 parasite species. Although the monkey goby was infected with 11 parasite species has the richest parasite fauna, the marbled goby was infected with only 4 parasite species. The highest prevalence and abundance values (77.8\% and 49.02) were found in tubenose goby infected with 9 parasite species (Table 1).

The monogenean Gyrodactylus proterorhini and the digenean metacercariae Tylodelphys clavata and Echinostoma sp. were determined in three gobiid fishes. Contraceacum rudolphii occurred only in tubenose goby; Spiroxys contortus and Eustrongylides excisus were found only in monkey goby, and Gyrodactylus sp. occurred only in marbled goby (Table 1). Four species, G. proterorhini, Apatemon gracilis, Posthodiplostomum sp., and Echinostoma sp., played core roles in the metazoan parasite faunas of gobies from the Lower Kızılırmak Delta. G. proterorhini, A. gracilis, and Posthodiplostomum sp. were essential in the tubenose goby parasite fauna and Echinostoma sp. in the monkey and tubenose goby parasite faunas. Moreover, Echinostoma sp. was core in all cases except in marbled goby (Table 1).

The species composition of metazoan faunas of the three gobiid species differed, and the parasite species richness was variable among the gobiid fishes. The metazoan parasite fauna of the marbled goby, which is of Mediterranean origin, differed markedly from those of the monkey and tubenose gobies (Table 1). The homogeneity of the parasite component faunas was low in monkey and tubenose gobies, but it was high in marbled goby (Table 2). The mean infracommunity index (ICl) of the monkey goby was higher than that of the marbled goby. The $\mathrm{ICl}$ of the tubenose goby differed from that of the monkey and marbled gobies (Table 2). A high Czekanowski-Sorensen index, indicating a close similarity, was observed in the metazoan parasite fauna of the monkey and tubenose gobies (Ics=80.0\%) (Table 3).

\section{DISCUSSION}

Data on parasites of various gobiid fishes found in the Black Sea coast are previously reported (12-17, 20, 21, 29-31). These studies include the parasites of the three gobiid species ( $N$. fluviatilis, Pr. marmoratus, and Po. marmoratus) and 34 metazoan parasite species (Table 4). We found 13 parasite species; 6 species were reported on in a previous study, but 7 species, including Gyrodactylus sp., Bothriocephalus acheilognathi, Echinostoma 
Table 4. List of the metazoan parasites reported from three gobiid fishes in different geographical localities in the Black Sea region

\begin{tabular}{|c|c|c|c|}
\hline & Neogobius fluviatilis & Proterorhinus marmoratus & Pomatoschistus marmoratus \\
\hline Gyrodactylus proterorhini & [43], Present study & [43], [20], [21], Present study & Present study \\
\hline Gyrodactylus leopardinus & & & [30] \\
\hline Gyrodactylus sp. & & & Present study \\
\hline Ascocotyle sp. met. & Present study & & \\
\hline Echinostoma sp. met. & Present study & Present study & Present study \\
\hline Tylodelphys clavata met. & [31] Present study, & Present study & Present study \\
\hline Diplostomum spathaceum & [21], [31] Present study & Present study & \\
\hline Apatemon gracilis met. & [31] Present study & Present study & \\
\hline Posthodiplostomum sp. met. & Present study & Present study & \\
\hline Cryptocotyle concavum met. & [12], [13], [14], [16], [21], [32], [43] & [10], [15], [16], [17], [20], [21] & [10], [15], [16], [29], [21] \\
\hline Cryptocotyle lingua met. & {$[12],[13],[16],[21],[43]$,} & {$[16],[17],[20],[21]$} & [15], [16], [21], [29] \\
\hline Pygidiopsis genata met. & {$[12],[13],[16],[21],[31]$} & [20], [21] & [21], [29] \\
\hline Acanthostomum imbutiformis & [10], [21], [31], [43], & [20], [21] & [15], [16], [21], [29] \\
\hline Stephanostomum bicoranatum & & [43] & \\
\hline Monascus filiformis & [43] & [43] & \\
\hline Pronopyrmna ventricosa & [43] & [43] & [31] \\
\hline Pronopyrmna petrowi & [43] & [43] & \\
\hline Magnibursatus skrjabini & & [20], [21] & \\
\hline Asymphylodora imitans & [31] & & \\
\hline Asymphylodora pontica & [21] & & [15], [16], [21], [29] \\
\hline Aphalloides coelomicola & & & [15], [16], [21], [29] \\
\hline Galactosomum lacteum & [43] & & \\
\hline Paratimonia gobii & & & [15], [16], [21], [29] \\
\hline Nicolla skrjabini & [16], [31] & & \\
\hline Holostephaluscobitis met. & [31] & & \\
\hline Ichthyocotylurus variegatus & [31] & & \\
\hline Rhipidocotyle companula met. & [31] & & \\
\hline Maritrema subdolum met. & [10] & & \\
\hline Proteocephalus gobiorum & {$[12],[16],[31]$} & [20] & \\
\hline Proteocephalus torulosus & [31] & & \\
\hline Ligula pavlovskii & {$[13],[14],[16]$} & & \\
\hline Bothriocephalus gregarius & & & [16], [29] \\
\hline Bothriocephalus acheilognathi pl. & Present study & Present study & \\
\hline Agamonema sp. L3 & [31] & & \\
\hline Contraceacum rudolphii L3 & [21] & [21], Present study & \\
\hline Contraceacum microcephalum & & & [29] \\
\hline Eustrongylides excisus L3 & [14], [16], [31], & & \\
\hline \multicolumn{4}{|l|}{ Present study } \\
\hline Dichelyne minutus & {$[12],[14],[16],[21],[31]$} & [15], [16], [17], [20], [21] & [15], [16], [29], [21] \\
\hline Cucullanus heterochrous & [43] & & \\
\hline Streptocara crassicauda & [31] & [20] & \\
\hline Raphidascaris acus & {$[14],[16],[31]$} & & \\
\hline Pseudocapillaria tomentosa & [13] & & \\
\hline Spiroxys contortus & Present study & & \\
\hline Acanthocephaloides propinquus & {$[12],[13],[16],[31]$} & {$[12],[16],[17],[20]$} & [16], [29] \\
\hline Telosentis exiguus & {$[10],[12],[16]$} & [20] & [16] \\
\hline Ergasilus sieboldi & Present study & & \\
\hline Thersitina gasterostei & [43] & & \\
\hline
\end{tabular}


sp., Posthodiplostomum sp., Ascocotyle sp., S. contortus, and Ergasilus sieboldi, were mentioned from the three examined gobiids for the first time in the Black Sea (Table 4). Parasites such as the trematodes Pygidiopsis genata (metacercaria), Cryptocotyle concavum met., Cryptocotyle lingua met., and Timoniella imbutiforme met., nematode Dichelyne minutus, and acanthocephalan Acanthocephaloides propinquus were previously observed in the three gobiids in various sites of the northwestern Black Sea and Crimean coasts. Overall, these parasite species are typical for the resident gobiids in the Black Sea, but we did not find them during our study. C. concavum, C. lingua, P. genata, T. imbutiforme, D. minutus, and $A$. propinquus are brackish water and marine parasite species. Moreover, the first intermediate hosts of these parasites are also absent in fresh waters $(7,14)$. The absence of parasites mentioned in the present study could be explained by low salinity in our study area (approximately 1\%).

According to previous studies, five of the listed species, G. proterorhini, A. gracilis, T. clavata, Diplostomum spathaceum, and $E$. excisus, have been reported in the monkey goby from different localities of the Black Sea (14, 16, 21, 31, present study) (Table 4). Similarly, G. proterorhini and C. rudolphii have been previously reported in the tubenose goby $(20,21)$. G. proterorhini is a specific species for gobiids inhabiting the Black and Azov Seas and their estuaries (32). Additionally, it is reported in various rivers belonging to the Black Sea drainage within the natural living area of the Ponto-Caspian gobiids $(20,29,33)$. To date, Zosterisessor ophiocephalus, Gobius cobitis, Gobius niger, N. melanostomus, N. fluviatilis, Neogobius platyrostris, Mesogobius batrachocephalus, and Neogobius kessleri have been reported as host of $G$. proterorhini $(19,23,34-40)$. To the best of our knowledge, the occurrence of $G$. proterorhini in Po. marmoratus is reported for the first time in this study. A new host has been added to the host list of $G$. proterorhini. Until today, three Gyrodactylus species that are known to parasitize Po. Marmoratus include $G$. branchialis and $G$. ostendicus that are reported from the western Mediterranean Sea (41) and G. leopardinus that is reported from the Azov Sea $(30,42)$.

To date, 47 metazoan parasite species have been mentioned in the Black Sea basin according to data from different authors (Table 4). We found 13 parasite species; 7 of these had already been mentioned in published studies, but 6 species, Ascocotyle sp., Posthodiplostomum sp., Echinostoma sp., B. acheilognathi, $S$. contortus, and E. sieboldi, were mentioned from three gobiid fishes for the first time. Particularly, tendency to join the infracommunity of Echinostoma sp., which is a limnetic parasite species, differs from other parasites in the present study (Table 2). The species composition of the metazoan fauna of gobiid fishes from the Lower Kızılırmak Delta located on the southern coastal zones of the Black Sea differed from those reported from various sites of the northern coastal zone of the Black Sea. The results of the present study indicated that the euryhaline and limnetic species are prevalent in this basin, but the marine and brackish water species are prevalent in its northern part. The gobiid parasite fauna does not show homogeneity in the Black Sea (34). It consists of Ponto-Caspian, Mediterranean, Boreal-Atlantic, and limnetic parasite species that are attributed to the different ranges of euryhalinity of the hosts. Thus, the species composition of the gobiid metazoan fauna in the present study is formed according to the ecology of the host species.

\section{CONCLUSION}

The present study comprises current data regarding the metazoan parasite fauna of gobiids in the Lower Kızılırmak Delta from the Black Sea. The data presented in this paper contribute to the list of parasite species that inhabit this basin. In general, the metazoan parasite communities of the three gobiid fishes from the Lower Kızılırmak Delta comprised limnetic species and differed from the other regions of the Black Sea.

Ethics Committee Approval: Ethics committee approval was received for this study from the Animal Experiments Local Ethics Committee of Sinop University (Date: 01.03.2010).

Peer-review: Externally peer-reviewed.

Author contributions: Concept - T.Ö., A.G.; Design - T.Ö., A.G.; Supervision - T.Ö., A.G.; Resource - T.Ö., A.G.; Materials - T.Ö., A.G.; Data Collection and/or Processing - A.G., T.Ö.; Analysis and /or Interpretation - T.Ö., A.G.; Literature Search - A.G. T.Ö.; Writing - T.Ö.; Critical Reviews - T.Ö., A.G.

Acknowledgements: The authors would like to thank Prof. Dr. Ahmet ÖZER who shared their valuable opinions during the study.

Conflict of Interest: No conflict of interest was declared by the authors.

Financial Disclosure: This study was financially supported by the Scientific and Technological Research Council of Turkey (TÜBITAK; project number $1,100,424)$. The authors are grateful for their valuable support.

Etik Komite Onayı: Bu çalışma için etik komite onayı Sinop Üniversitesi, Hayvan Deneyleri Yerel Etik Kurulu'ndan (01.03.2010) alınmıştır.

Hakem Değerlendirmesi: Dış bağımsız.

Yazar Katkıları: Fikir - T.Ö., A.G.; Tasarım - T.Ö., A.G.; Denetleme - T.Ö., A.G.; Veri Toplanması ve/veya İşlemesi - A.G., T.Ö.; Analiz ve/veya Yorum - T.Ö., A.G.; Literatür Taraması - A.G., T.Ö., Yazıyı Yazan - T.Ö.; Eleştirel Inceleme - T.Ö., A.G.

Teşekkür: Yazarlar, çalışmanın yürütülmesinde değerli görüşlerini bizlerle paylaşan Prof. Dr. Ahmet ÖZER'e teşekkür ederler.

Çıkar Çatışması: Yazarlar çıkar çatışması bildirmemişlerdir.

Finansal Destek: Bu çalışma, Türkiye Bilimsel ve Teknolojik Araştırma Kurumu (TÜBITAK, proje numarası 1104244) tarafından maddi olarak desteklenmiştir.

\section{REFERENCES}

1. Nelson JS. Fishes of the orld. Third edition. Jhon Wiley and Sons, Inc New York; 1994. p. 600.

2. Smirnov Al. Percifomes (Gobioidei), Scorpaeniformes, Pleuronectiformes, Lophiiformes (in Russian). Fauna Ukraini 1986; 8: 183-7.

3. Miller PJ. The freswater fishes of Europe. Vol. 8. Part II. Gobiidae 2. Wiebelsheim, Germany, AULA Verlag; 2004. p. 477.

4. Prasek V, Jurajda P. Expansion of Proterorhinus marmoratus in the Morava River Basin (Czech Republic, Danube R. watershed). Folia Zool 2005; 54: 189-92.

5. Neilson ME, Stepien CA. Historic speciation and recent colonization of Eurasian monkey gobies (Neogobius fluviatilis and N. pallasi) revealed by DNA sequences, microsatellites and morphology. Diversity and Distributions 2011; 17: 1-15. [CrossRef] 
6. Keskin Ç. A Review of fish fauna in the Turkish Black Sea. Journal Black Sea Mediterranean Environment 2010; 16: 210-95.

7. Zander CD, Strohbach U, Groenewold S. The importance of gobies (Gobiidae: Teleostei) as hosts and transmitters of parasites in the sw Baltic. Helgolander Meeresunters 1993; 47: 81-111. [CrossRef]

8. Zander CD, Kestıng V. Colonization and seasonality of goby (Gobiidae, Teleostei) parasites from the southwestern Baltic Sea. Parasitol Res 1998; 84: 459-66. [CrossRef]

9. Chernyshenko AS. Parasite fauna of fish of the estuaries of the north-western Black Sea region (ecological faunistic review). In Vodyanıtskiy VA, Vınogradov KA, Dolgopolskaya MA, Greze VN, Revin AS, Kalugina AA, Denisenko IF, Delamur SL (Eds). Helminth fauna of animals of the southern seas. Naukova Dumka, Kiev; 1966. p. 105-13 (in Russian).

10. Machkevsky VK, Mordvinova TN, Parukhin AM. The helminth fauna of gobiids of the gulf of Yegorlyk and Donuzlav lake-places of the mussel farms. Ekologiya Morya 1990; 36: 69-75.

11. Kvach Y. Helminthes of gobies from the Tuzly's Lagoons (North-Western Part of The Black Sea). Oceanological Studies 2001; 30: 103-13.

12. Kvach Y. Helminthes of goby fish of the Hryhoryivsky Estuary (Black Sea, Ukraine). Vestnik Zoologii 2002a; 36: 71-76.

13. Kvach Y. Helminths parasitising gobies and other fishes in the Budaksky Lagoon (Black Sea, Ukraine). Oceanological Studies 2002b; 31: 59-65.

14. Kvach Y. The metazoa parasites of gobiids in the Dniester Estuary (Black Sea) depending on water salinity. Oceanological and Hydrobiological Studies 2004a; 33: 47-56.

15. Kvach Y. The helminth fauna of gobiid fishes (Gobiidae) from the Tyligul Estuary of the Black Sea. Visnik L'vivs'kogo Universitetu, Biology Series 2004b; 37: 144-8.

16. Kvach Y. A comparative analysis of helminth faunas and infecton parameters of ten species of gobiid fishes (Actinopterygii: Gobiidae) from the north-western Black Sea. Acta Ichthyologica et Piscatoria 2005; 35: 103-10. [CrossRef]

17. Kvach Y. The helminth fauna of gobies (Gobiidae) of the Gulf of Odessa of the Black Sea. Vestnik Zoologii 2007; 41: 207-11.

18. Eros T, Sevcsik A, Toth B. Abundance and night-time habitat use patterns of Ponto-Caspian gobiid species (Pisces, Gobiidae) in the littoral zone of the River Danube, Hungary. Journal of Applied Ichthyology 2005; 21: 350-7. [CrossRef]

19. Ondrackova M, Davidova M, Pecinkova M, Blazek R, Gelnar M, Valova Z, et al. Metazoan parasites of Neogobius fishes in the Slovak section of the River Danube. Journal of Applied Ichthyology 2005; 21: 345-9. [CrossRef]

20. Kvach Y, Oğuz MC. Communities of metazoan parasites of two fishes of the Proterorhinus Genus (Actinopterygii: Gobiidae). Helminthologia 2009; 46: 168-76. [CrossRef]

21. Krasnovyd V, Kvach Y, Drobiniak $O$. The parasite fauna of the gobiid fish (Actinopterygii, Gobiidae) in the Sukhyi Lyman, Black Sea. Vestnik Zoologii 2012; 46: e1-8. [CrossRef]

22. Özer A. Trichodina domerguei Wallengren, 1897 (Ciliophora: Peritrichia) infestations on the round goby, Neogobius melanostomus Pallas, 1811 in relation to seasonality and host factors. Comparative Parasitology 2003; 70: 132-5. [CrossRef]

23. Özer A. Metazoan parasite fauna of the round goby Neogobius melanostomus Pallas, 1811 (Perciformes: Gobiidae) collected from the Black Sea coast at Sinop, Turkey. Journal of Natural History 2007; 41: 483-92. [CrossRef]

24. Öztürk T, Çam A. Trichodinid parasites (Protozoa: Ciliophora: Peritrichida) of invasive gobiid fish inhabiting the Lower Kızılırmak Delta in Samsun, Turkey. Pakistan Journal of Zoology 2013; 45: 1517-24.

25. Bush AO, Lafferty KD, Lotz JM, Shostak AW. Parasitology meets ecology on its own terms. Margolis et al revisted. J Parasitol 1997; 83: 575-83. [CrossRef]
26. Sorensen TA. A new method of establishing groups of equal amplitude in plant sociology based on similarity of species content and its application to analysis of vegetation on danish commons. Biologiske Skrifter 1948; 5: 1-34.

27. Zander CD. Four-year monitoring of parasite communities in gobiid fishes of the south-western Baltic. I. guild and component community. Parasitology Research 2003; 90: 502-11. [CrossRef]

28. Zander CD. Four-year monitoring of parasite communities in gobiid fishes of the south-western Baltic. II. Infracommunity. Parasitology Research 2004; 93: 17-29. [CrossRef]

29. Kvach Y. Helminths of the Marbled Goby (Pomatoschistus marmoratus), A Mediterranean immigrant in the Black Sea fauna. Vestnik Zoologii 2010; 44: 509-18. [CrossRef]

30. Dmitrieva EV, Skidan N. Gyrodactylus leopardinus sp. n. (Monogenea) a parasite of Pomatoschistus marmoratus (Gobiidae) from the Sea of Azov. Vestnik Zoologii 2005; 39: 17-22.

31. Kvach Y, Kornyychuk Y, Mierzejewska K, Rubtsova N, Yurakhno V, Grabowska J, et al. Parasitization of invasive gobiids in the eastern part of the central Trans-European corridor of invasion of PontoCaspian Hydrobionts. Parasitology Research 2014; 113: 1605-24. [CrossRef]

32. Ergens R. Nomenclatoric problems of Gyrodactylus gussevi Najdenova, 1966 and G. proterorhini Ergens, 1967 (Monogenoidea, Gyrodactylidae). Folia Parasitology 1972; 319-33.

33. Ergens R. New species of the genus Gyrodactylus (Monogenoidea) from the Danube Basin. Folia Parasitology (Praha) 1967; 14: 377-9.

34. Naidenova NN. Parasite fauna of fishes of the goby family from the Black and Azov Seas. Naukova Dumka, Kiev; 1974. p. 182.

35. Ergens R. Order Gyrodactylidea Bychowsky, 1937. In: Gusev AV (ed) Key to the parasites of the freshwater fish fauna of the USSR. Leningrad Nauka; 1985. p. 269-347.

36. Dmitrieva EV, Dimitrov G.Variability in the taxonomic characters of Black Sea Gyrodactylids (Monogenea). Systematic Parasitology 2002; 51: 199-206. [CrossRef]

37. Longshaw M, Pursglove M, Shinn AP. Gyrodactylus quadratidigitus n. sp. (Monogenea: Gyrodactylidae), a parasite of the leopard-spotted goby Thorogobius ephippiatus (Lowe) from the south-western coast of the UK. Systematic Parasitology 2003; 55: 151-7. [CrossRef]

38. Harris PD, Shinn AP, Cable J, Bakke TA. Nominal species of the genus Gyrodactylus von Nordmann 1832 (Monogenea: Gyrodactylidae), with a list of principal host species. Systematic Parasitology 2004; 59: 1-27. [CrossRef]

39. Ondrackova M, Davidova M, Blazek R, Gelnar M, Jurajda P. The interaction between an introduced fish host and local parasite fauna: Neogobius kessleri in the middle Danube River. Parasitology Research 2009; 105: 201-8. [CrossRef]

40. Mierzejewska K, Martyniak A, Kakareko T, Dzika E, Stańczak K, Hliwa P. Gyrodactylus proterorhini Ergens, 1967 (Monogenoidea, Gyrodactylidae) in gobiids from the Vistula River the first record of the parasite in Poland. Parasitology Research 2011; 108: 1147-51. [CrossRef]

41. Huyse T, Pampoulıe C, Audenaert V, Volckaert FAM. First report of Gyrodactylus spp. (Platyhelminthes: Monogenea) in the Western Mediterranean Sea: molecular and morphological descriptions. J Parasitol 2006; 92: 682-90. [CrossRef]

42. Gaevskaya AV. Parasites and diseases of fishes in the Black Sea and the Sea of Azov. I.-Sevastopol: EKOSI-Gidrofizika; 2012. p. 380.

43. Gaevskaya AV, Korniychuk YM. Parasitic organisms as a component of ecosystems of the Black Sea near-shore zone of Crimea. In: Modern condition of biological diversity in near-shore zone of Crimea (the Black Sea sector) In: VN Eremeev AV, Gaevskaya (Eds.), NAS Ukraine, Institute of Biology of the Southern Seas. EKOSIGidrophizika. Sevastopol; 2003. p. 425-90. 